\title{
Thermal Performance Evaluation of Curtain Wall Frame Types
}

\author{
Yong Woo Song ${ }^{1}$, Jin Chul Park ${ }^{2}$, Min Hee Chung ${ }^{3}$, Byung Do Choi ${ }^{1}$ and Jung Ha Park ${ }^{1}$ \\ ${ }^{1}$ Graduate Student, School of Architecture and Building Science, Chung Ang University, Republic of Korea \\ ${ }^{2}$ Professor, School of Architecture and Building Science, Chung Ang University, Republic of Korea \\ ${ }^{3}$ Professor, Department of Architecture, Soongsil University, Republic of Korea
}

\begin{abstract}
This study is an evaluation of thermal performance according to curtain wall frame types. Heat transfer simulations were conducted on the currently preferred aluminum, steel and scagliola frames, which improved thermal performance and actual frames were produced for thermal performance experiments. The results of this study can be summarized as follows: when heat transfer simulation was conducted to compare the thermal performance of the three frames for summer and winter, scagliola showed the lowest temperature difference, both inside and outside with excellent thermal performance compared to the aluminum/steel frame. Also, as a result of a mock-up test based on the simulation results, for both night and day, the temperature difference was found to be lowest for the scagliola frame. Therefore, it was found that by applying the scagliola frame which improves on the thermal performance of the aluminum/steel frame, the heat loss from frames can be reduced.
\end{abstract}

Keywords: curtain wall frame; steel frame; aluminum frame; scagliola frame; frame simulation(Therm6.3, Window6.3)

\section{Introduction}

Facades are the elements that complete the overall form of buildings, and can express their character, while they are also an important factor in energy savings (Lam et al., 2005; Sozer, 2010; Sadinen et al., 2011). Recently, full size curtain walls have been used for the exteriors of buildings (Cho et al., 2010). Overall curtain wall thermal performance is a function of the glazing infill panel, frame, construction behind opaque areas, and perimeter details (Clarke et al. 1998; Ganguli and Quirouette 1987; Richmana and Pressnailb, 2010; Ge, 2002). In particular, curtain wall frame conductance is one of the important parameters for thermal performance, because of heat loss through the wall. Curtain walls can have differences in thermal performance depending on the materials used for the frames(Ge and Fazio, 2004). Aluminum frames are the most often used, as they can be produced in any form the designer wants and the material enables the construction of lightweight curtain walls. Steel frames are widely used alongside aluminum frames, and they have less deflection than aluminum, so they can handle a larger size of glass. However, both aluminum frames and steel frames have a very high thermal

*Contact Author: Jin Chul Park, Professor,

School of Architecture and Building Science,

Chung Ang University, Heukseok-ro 84, Dongjak-gu, Seoul, Korea

Tel: +82-2-820-5261 Fax: +82-2-812-4150

E-mail: jincpark@cau.ac.kr

(Received October 9, 2012 ; accepted March 15, 2013) conductivity. This translates into high heat loss through aluminum or steel curtain wall mullions. On the other hand, scagliola has lower thermal conductivity, which improves thermal performance. Scagliola frames are based on steel frames, and are attached on the interior to reduce heat conductivity, and improve aesthetics and performance.

In this study, simulation and mock-up tests were conducted on the thermal performance according to the type of frame, which is an element of a curtain wall. The performances of curtain wall frames were analyzed through simulation and mock-up tests. The details of this study are as follows.

1) Existing curtain wall frame-related studies were reviewed.

2) A heat transfer simulation for curtain wall frames was executed, and the thermal performance for each type of curtain wall frame was found.

3) Each type of curtain wall frame was produced and a mock-up test was executed to measure and analyze the thermal performance of the frames.

This paper is intended to be utilized as an elementary resource for the performance enhancement of curtain wall frames.

\section{Literature Review}

\subsection{Curtain Wall and Frame}

There are diverse studies of curtain walls and frames. Kim et al. (2005) introduced a new prediction method regarding condensation, using a numerical simulation program. Song et al. (2006) evaluated 
energy and surface dew condensation prevention, using low-e coating and insulation spacers. Lee et al. (2009) executed an artificial solar laboratory (A.S.L), for performance evaluation of $24 \mathrm{~mm}$ transparent glass applied to a typical curtain wall. Yoon et al. (2009), used WEPT tools to quickly identify the most cost-effective and selected algorithm, by applying the energy analysis Trnsys program. Cho et al. (2010), conducted a survey on the characteristics of prospective consumers for super-high-rise curtain walls, by surveying market trends and types of steel curtain wall.

Lee et al. (2011) studied steel and aluminum frames, in order to enhance the fireproof performance of curtain walls.

Koo and Oh (2011) explored the use of fireproof, lightweight inorganic foam board, as an improvement for lightweight curtain wall systems made of aluminum and glass materials.

As a result of analyzing the existing Korean curtain wall studies, it can be seen that there have been numerous recent studies on the fireproof performance of curtain walls, but there has been a lack of studies comparing the thermal performance of different frames. Overseas, Miloslav and Martin (2011) dealt with a theoretical design of the contact between a frame and the window/door system. Also, there were studies on aspects of bonding, heat bridging, dew condensation prevention with glass, and sealant of diverse curtain walls. However, studies on the characteristics of materials applied to curtain wall frames and the execution of cross comparisons were inadequate just as in like the Korean situation.

\subsection{Thermal Performance Evaluation of Curtain Wall Frames}

No and Kim (2005) verified the conduction state of curtain wall materials through simulation, as well as evaluating the insulation efficiency and moisture condensation. However the air flow in the curtain wall frame was not considered and only a comparison and evaluation of aluminum and metal frames was conducted. Also, another study by No and Jeong (2011) compared general curtain walls commonly used in Korea, through both simulation and a lifesize experiment. Here, however, the same material was used for the curtain wall frame, and there were no comparisons on the application of different curtain wall frame materials.

Therefore, as a result of the resource analysis on the precedent studies, it was found that most of the currently used curtain walls are metallic or aluminum frames, and the heat bridge phenomenon is a weakness, thus, studies to improve on these are required.

\section{Simulation According to the Type of Curtain Wall Frame}

\subsection{Methodology}

A thermal performance simulation according to the curtain wall frame was conducted on three frames from the preceding section. Simulation results for the types of curtain wall frames were generated using THERM6.3 and WINDOW 6.3 which have been developed by the Lawrence Berkeley National Laboratory (LBNL), THERM 6.3 is a two-dimensional effective conductivity heat transfer analysis program, while WINDOW6.3 is a publicly available computer program for calculating total window thermal performance indices. The boundary values and physical properties of each window/door were calculated, as shown in Table 1.

Table 1. Material Properties Used in Computer Simulations

\begin{tabular}{c|cccc}
\hline \multirow{2}{*}{$\begin{array}{c}\text { Frame } \\
\text { Types }\end{array}$} & $\begin{array}{c}\mid c \\
\text { Outdoor Frame } \\
\text { thermal } \\
\text { transmittance } \\
\text { coefficient } \\
\left(\mathrm{W} / \mathrm{m}^{2}\right)\end{array}$ & $\begin{array}{c}\text { Area } \\
\left(\mathrm{m}^{2}\right)\end{array}$ & $\begin{array}{c}\text { Thermal } \\
\text { transmittance } \\
\text { coefficient } \\
\left(\mathrm{W} / \mathrm{m}^{2} \mathrm{~K}\right)\end{array}$ & $\begin{array}{c}\text { Area } \\
\left(\mathrm{m}^{2}\right)\end{array}$ \\
\hline Aluminum & 5.45 & 0.56 & 10.3 & 0.254 \\
Steel & 5.12 & 0.56 & 9.1 & 0.254 \\
Scagliola & 5.20 & 0.51 & 7.2 & 0.243 \\
\hline
\end{tabular}

The simulation was divided into summer and winter. Summer was set to an external temperature of $32^{\circ} \mathrm{C}$ and an internal temperature of $26^{\circ} \mathrm{C}$. Winter was set to an external temperature of $-10^{\circ} \mathrm{C}$ and an internal temperature of $22^{\circ} \mathrm{C}$.

\subsection{Results and discussion}

(1) Summer

The summer simulation results are shown in Figs.1.3. and Table 2 .

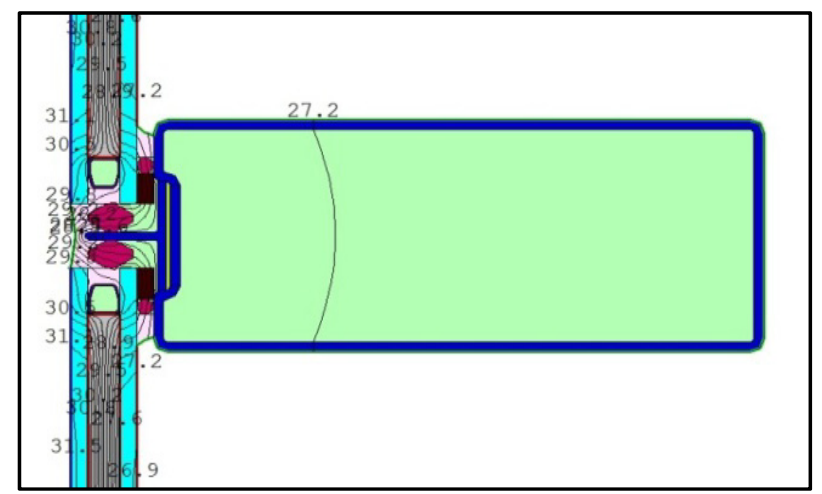

Fig.1. Aluminum Simulation Result (Summer)

For summer, the temperature difference for scagliola was found to be the smallest $\left(1.6^{\circ} \mathrm{C}\right)$. For steel and aluminum, the temperature difference was very large with 3 and $2^{\circ} \mathrm{C}$, respectively. The temperature difference means the temperature difference between inner and outer frames.

(2) Winter

The winter simulation results are shown in Figs.4.-6. and Table 3.

For winter, the temperature difference was large compared to summer. Steel showed the largest difference. For scagliola, the temperature difference 


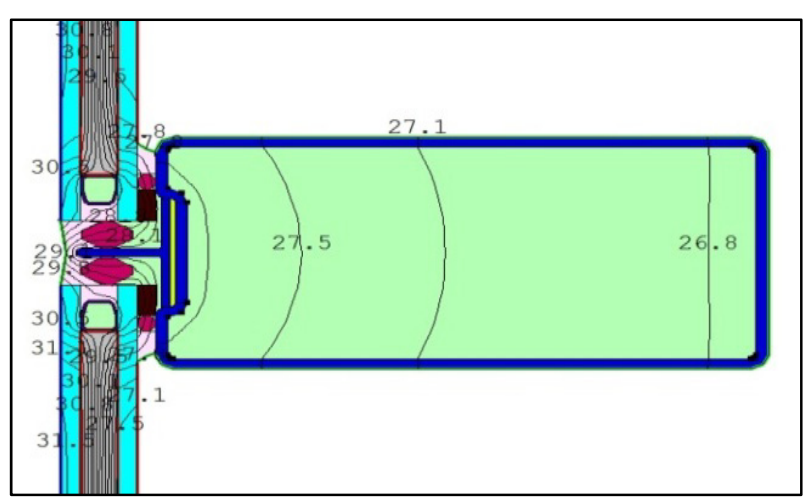

Fig.2. Steel Simulation Result (Summer)

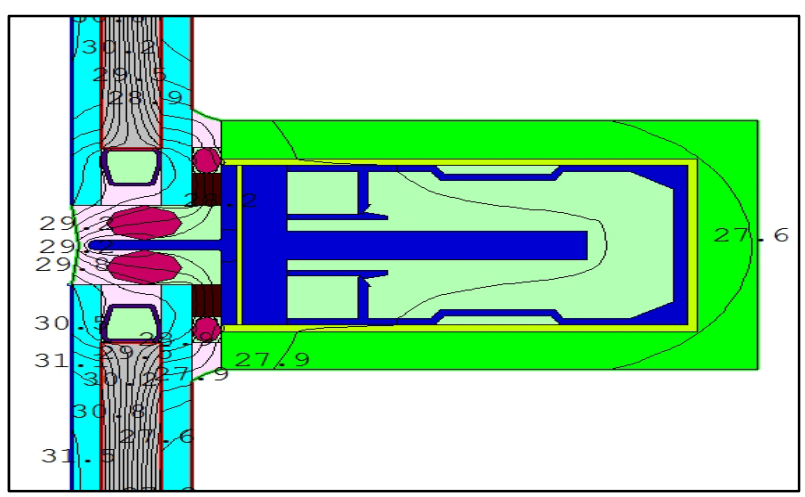

Fig.3. Scagliola Simulation Result (Summer)

Table 2. Simulation Temperature Results (Summer) $\left({ }^{\circ} \mathrm{C}\right)$

\begin{tabular}{c|ccc}
\hline Frame types & Aluminum & Steel & Scagliola \\
\hline $\begin{array}{c}\text { Temperature } \\
\text { (Outdoor) }\end{array}$ & 29.2 & 29.8 & 29.2 \\
Temperature & 27.2 & 26.8 & 27.6 \\
(Indoor) & 2.0 & 3.0 & 1.6 \\
$|\Delta \mathrm{t}|$ & & & \\
\hline
\end{tabular}

was smaller than that of aluminum $\left(10^{\circ} \mathrm{C}\right)$ and steel $\left(12.7^{\circ} \mathrm{C}\right)$. This means that the scagliola frame has less heat loss from inside to outside.

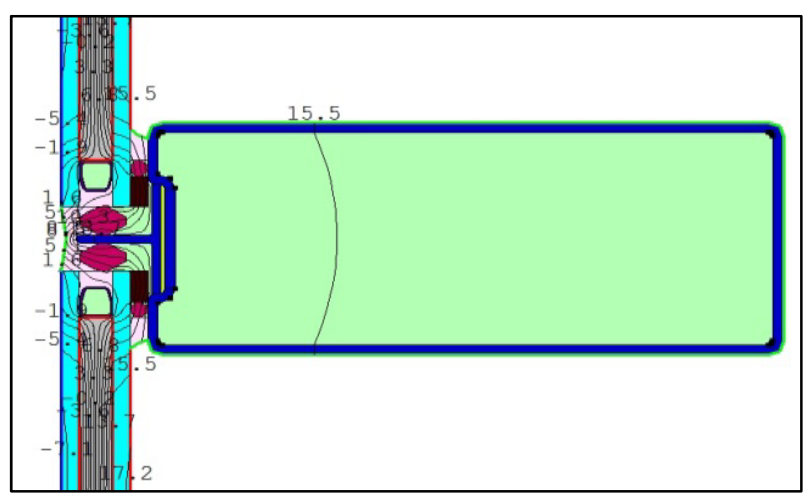

Fig.4. Aluminum Simulation Result (Winter)

As a result of analyzing the three frames of aluminum, steel, and scagliola using the heat transfer simulation, it can be seen that the scagliola frame has little heat loss, both for summer and winter.

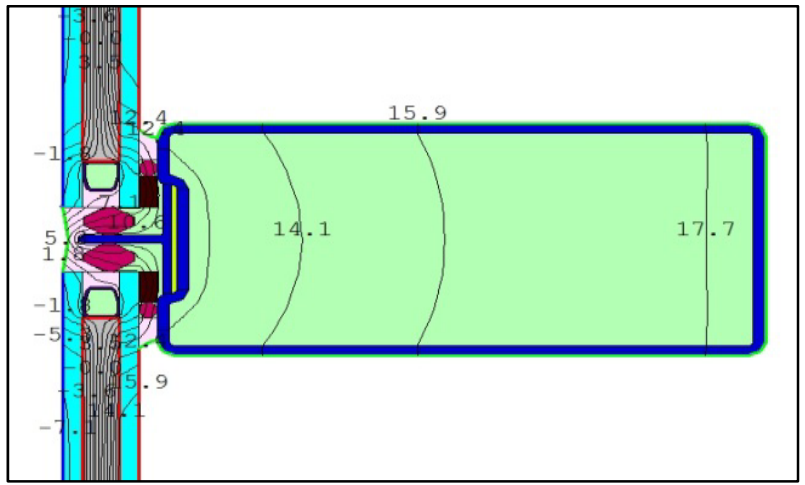

Fig.5. Steel Simulation Result (Winter)

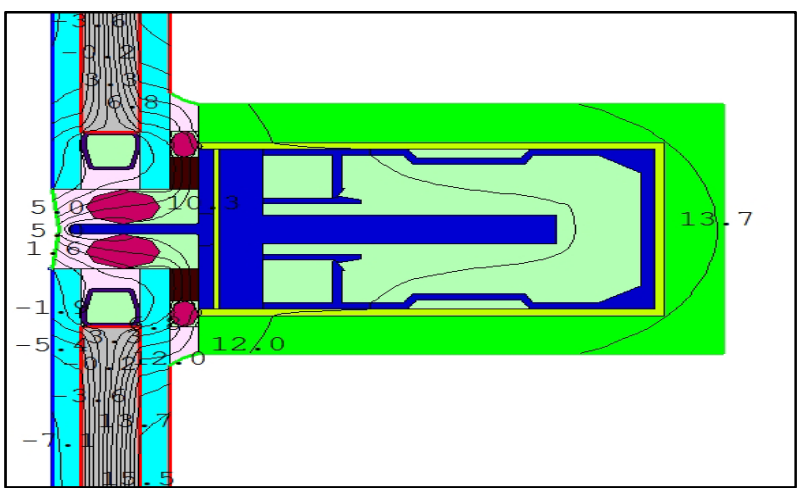

Fig.6. Scagliola Simulation Result (Winter)

Table 3. Simulation Temperature Results (Winter) $\left({ }^{\circ} \mathrm{C}\right)$

\begin{tabular}{c|ccc}
\hline Frame types & Aluminum & Steel & Scagliola \\
\hline $\begin{array}{c}\text { Temperature } \\
\text { (Outdoor) }\end{array}$ & 5.5 & 5.0 & 5.0 \\
$\begin{array}{c}\text { Temperature } \\
\text { (Indoor) }\end{array}$ & 15.5 & 17.7 & 13.7 \\
$|\Delta \mathrm{t}|$ & 10.0 & 12.7 & 8.7 \\
\hline
\end{tabular}

\section{Mock-up Test}

\subsection{Methodology}

In order to verify the thermal performance according to the types of curtain wall frame found in the previous simulation, a mock-up experiment building was constructed.

For the mock-up test, three different test rooms were constructed per frame material Room A (aluminum frame), Room B (steel frame), and Room C (scagliola frame), as shown in Figs.7.-12.

Each room was finished with and had the same size and panel material. Also, the frame and glazing were installed on the south side among the four vertical walls, as shown in Fig.13.

The temperature was measured by installing T-type sensors in four locations of the room indoors and outdoors of the frame and glass for each room. Indoor sensors were installed in the middle of each room, at heights of FL+200,1,500,2,000mm, as shown in Fig. 14.

Because the measurement period was summer, airconditioning was applied, and the temperature changes 


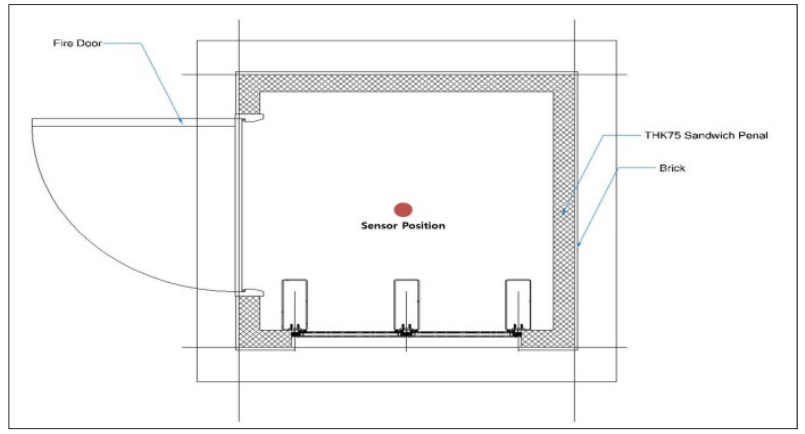

Fig.7. Aluminum Chamber Plan

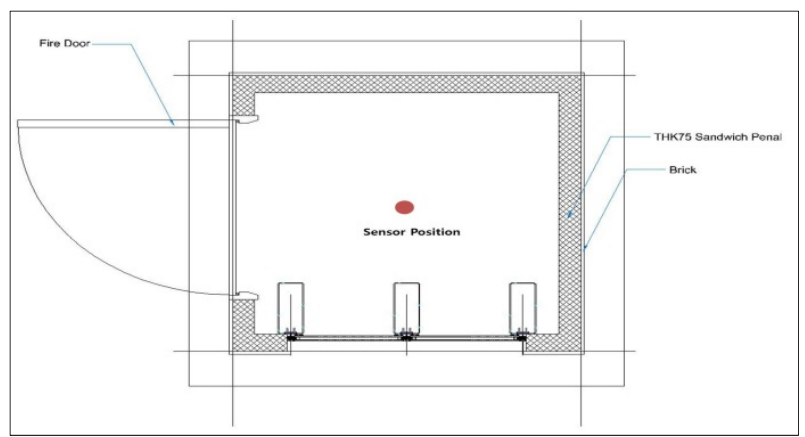

Fig.9. Steel Chamber Plan

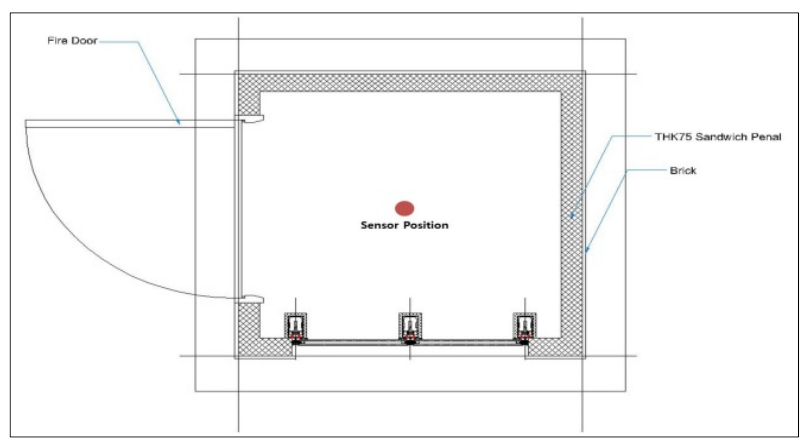

Fig.11. Scagliola Chamber Plan

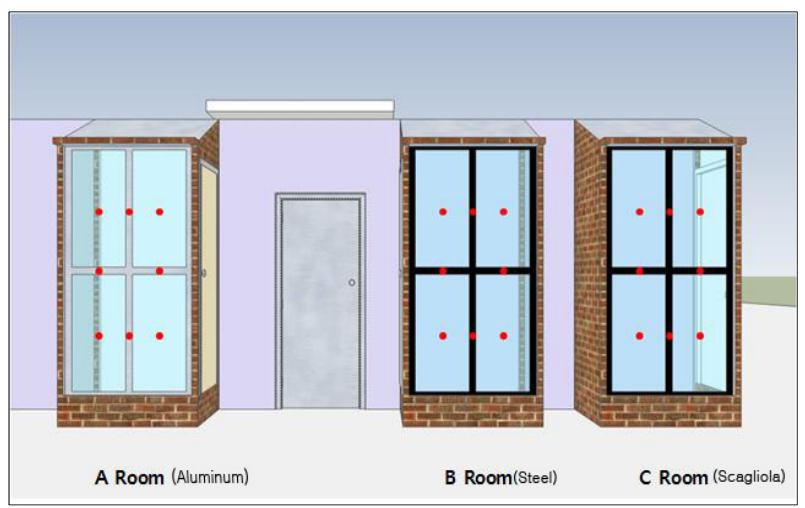

Fig.13. Sensor Position of Mock-Up Test-Bed(1)

at the indoor/outdoor and frames were measured according to the change in external air temperature over a certain period of time.

\subsection{Mock-up Test result and discussion}

The experiment was divided into night and day.

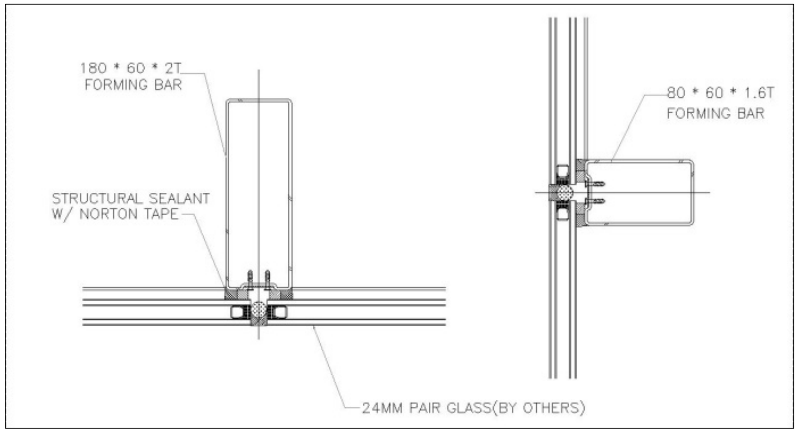

Fig.8. Aluminum Frame Detail

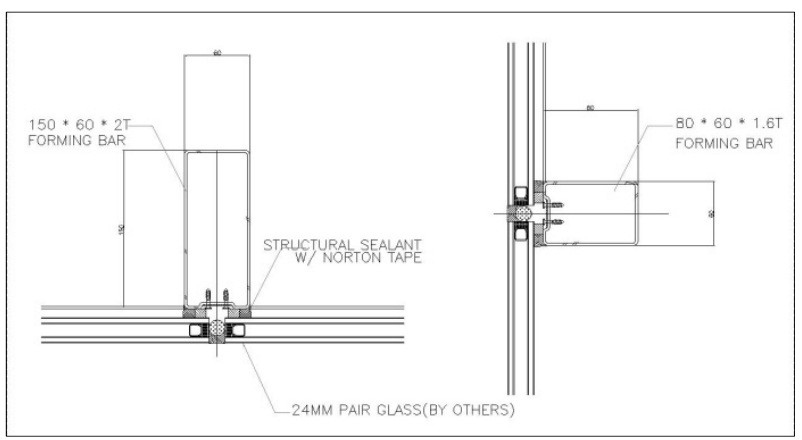

Fig.10. Steel Frame Detail

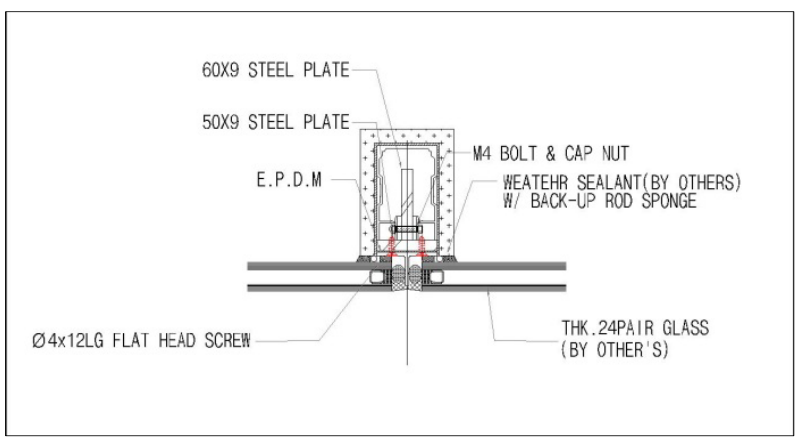

Fig.12. Scagliola Frame Detail

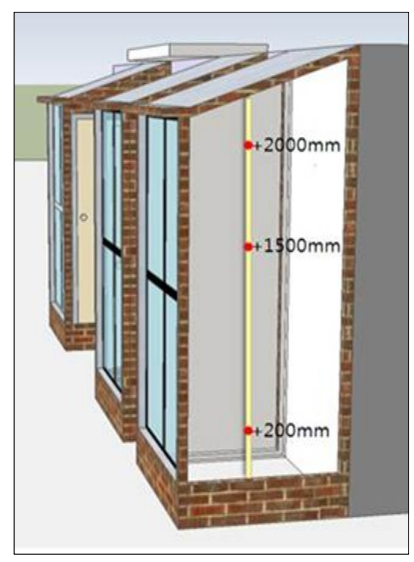

Fig.14. Sensor Position of Mock-Up Test-Bed(2)

In the daytime, the influence of the daylight and the external temperature was considered. In the nighttime, only the external air temperature was considered without the influence of sunlight. The experiment 
results were compared and analyzed against the following items.

(1) Temperature change of indoor frame

(Aug. $1^{\text {st }}-18^{\text {th }}$ )

(2) Temperature change of outdoor frame

(Aug. 19 $-25^{\text {th }}$ )

Table 4. shows the mean for each temperature type.

Table 4. Definition of Each Temperature Type

\begin{tabular}{l|l}
\hline \multicolumn{1}{c|}{ Type } & \multicolumn{1}{c}{ Temperature mean } \\
\hline Start temp. & $\begin{array}{l}\text { The Initial temperature of each frame and } \\
\text { structure, before using the cooling device. }\end{array}$ \\
Desired temp. & $\begin{array}{l}\text { Indoor set temperature using the cooling device } \\
\text { Temperature(Stop cooling device) }\end{array}$ \\
A/C off & $\begin{array}{l}\text { After the cooling system was operated, the final } \\
\text { temperature for the experiment that exposed } \\
\text { the room to external influences during a certain } \\
\text { period (time of exposure to the outside after A/ } \\
\text { C was turned off : 1 3hours) } \\
\text { Each Frame Temperature difference }\end{array}$ \\
\hline$\Delta \mathrm{t} \mid$
\end{tabular}

(A) Daytime Indoor Frame Temperature Distribution

The temperatures of the frames measured indoor during the daytime are shown in Table 5. and Fig.15.

Table 5. Indoor Frame Temperature (Daytime) $\left({ }^{\circ} \mathrm{C}\right)$

\begin{tabular}{c|ccccc}
\hline $\begin{array}{c}\text { Room } \\
\text { name }\end{array}$ & $\begin{array}{c}\text { Start } \\
\text { temp. } \\
\left({ }^{\circ} \mathrm{C}\right)\end{array}$ & $\begin{array}{c}\text { Desired } \\
\text { temp. } \\
\left({ }^{\circ} \mathrm{C}\right)\end{array}$ & $\begin{array}{c}\mathrm{A} / \mathrm{C} \\
\text { off }[\mathrm{C}] \\
\left({ }^{\circ} \mathrm{C}\right)\end{array}$ & $\begin{array}{c}\text { Off temp. } \\
{[\mathrm{D}]}\end{array}$ & $\begin{array}{c}|\Delta \mathrm{t}| \\
{[\mathrm{D}]-[\mathrm{C}]}\end{array}$ \\
\hline RoomA & 38.8 & 21.7 & 25.7 & 42.2 & 16.5 \\
RoomB & 40.3 & 21.7 & 28.0 & 45.6 & 17.6 \\
RoomC & 38.4 & 21.7 & 30.2 & 40.1 & 9.9 \\
\hline
\end{tabular}

Room A : Aluminum, Room B : Steel, Room C : Scagliola

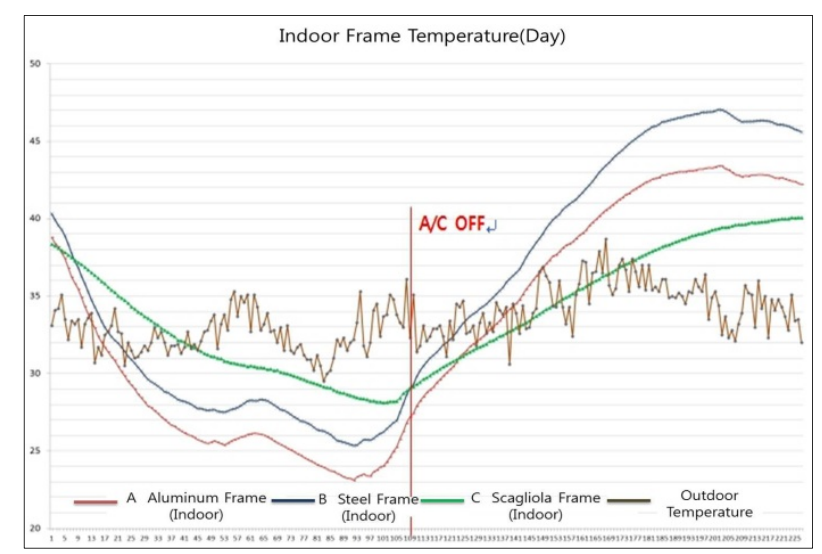

Fig.15. Indoor Frame Temperature (Day)

In the temperature change results for the daytime indoor frame, the internal temperature of the scagliolaapplied frame was found to be about $30.2^{\circ} \mathrm{C}$. The aluminum and steel frames were $25.7^{\circ} \mathrm{C}$ and $28.0^{\circ} \mathrm{C}$, respectively, which was about $2-5^{\circ} \mathrm{C}$ lower than that of the scagliola-applied frame.

It can be seen that the coldness was conducted through the frame due to the higher heat conductivity of aluminum and steel, as compared to that of the scagliola-applied frame.

Due to the influence of the external air temperature and daylight after termination of the air-conditioning, the temperature rose rapidly for the steel and aluminum frames.

(B) Daytime Outdoor Frame Temperature Distribution

The temperatures measured during the daytime and outdoors are shown in Table 6. and Fig. 16.

Table 6. Outdoor Frame Temperature (Daytime) $\left({ }^{\circ} \mathrm{C}\right)$

\begin{tabular}{c|ccccc}
\hline $\begin{array}{c}\text { Room } \\
\text { name }\end{array}$ & $\begin{array}{c}\text { Start } \\
\text { temp. } \\
\left({ }^{\circ} \mathrm{C}\right)\end{array}$ & $\begin{array}{c}\text { Desired } \\
\text { temp. } \\
\left({ }^{\circ} \mathrm{C}\right)\end{array}$ & $\begin{array}{c}\mathrm{A} / \mathrm{C} \text { off } \\
{[\mathrm{C}]} \\
\left({ }^{\circ} \mathrm{C}\right)\end{array}$ & $\begin{array}{c}\text { Off temp. } \\
{[\mathrm{D}]} \\
\left({ }^{\circ} \mathrm{C}\right)\end{array}$ & $\begin{array}{c}|\Delta \mathrm{t}| \\
{[\mathrm{D}]-[\mathrm{C}]} \\
\left({ }^{\circ} \mathrm{C}\right)\end{array}$ \\
\hline Room A & 39.5 & 21.7 & 36.5 & 41.4 & 4.9 \\
Room B & 41.5 & 21.7 & 37.7 & 43.9 & 6.2 \\
Room C & 40.2 & 21.7 & 40.8 & 41.3 & 0.5 \\
\hline
\end{tabular}

Room A : Aluminum, Room B : Steel, Room C : Scagliola

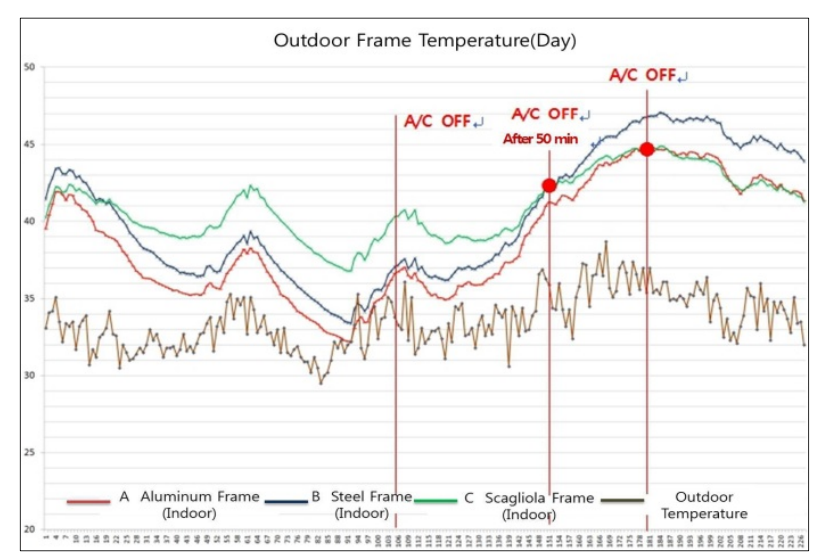

Fig.16. Outdoor Frame Temperature (Day)

The daytime outdoor frames' initial temperatures were $39.5^{\circ} \mathrm{C}, 41.5^{\circ} \mathrm{C}$, and $40.2^{\circ} \mathrm{C}$ for the aluminum, steel, and scagliola frame, respectively, When the indoor average temperature reached $21.7^{\circ} \mathrm{C}$ after airconditioning, the outdoor frame temperature was found to be $36.5^{\circ} \mathrm{C}$ for aluminum, $37.7^{\circ} \mathrm{C}$ for steel, and $40.8^{\circ} \mathrm{C}$ for scagliola.

Therefore, it was found that the scagliola frame showed the smallest temperature change.

(C) Nighttime Indoor Frame Temperature Distribution

The temperatures of the frames measured indoors and at night, without daylight, are shown in Table 7. and Fig. 17.

Table 7. Indoor Frame Temperature (Nighttime) $\left({ }^{\circ} \mathrm{C}\right)$

\begin{tabular}{|c|c|c|c|c|c|}
\hline Room name & $\begin{array}{l}\text { Start } \\
\text { temp. } \\
\left({ }^{\circ} \mathrm{C}\right)\end{array}$ & $\begin{array}{c}\text { Desired } \\
\text { temp. } \\
\left({ }^{\circ} \mathrm{C}\right)\end{array}$ & $\begin{array}{c}\mathrm{A} / \mathrm{C} \text { off } \\
{[\mathrm{C}]} \\
\left({ }^{\circ} \mathrm{C}\right) \\
\end{array}$ & $\begin{array}{c}\text { Off } \\
\text { temp. }[\mathrm{D}] \\
\left({ }^{\circ} \mathrm{C}\right)\end{array}$ & $\begin{array}{c}|\Delta \mathrm{t}| \\
{[\mathrm{D}]-[\mathrm{C}]} \\
\left({ }^{\circ} \mathrm{C}\right)\end{array}$ \\
\hline Room A & 27.7 & 18.1 & 18.6 & 25.7 & 7.1 \\
\hline Room B & 27.5 & 18.1 & 19.1 & 26.0 & 6.9 \\
\hline Room C & 29.4 & 18.1 & 22.2 & 26.7 & 4.5 \\
\hline
\end{tabular}

Room A : Aluminum, Room B : Steel, Room C : Scagliola

The indoor temperature of each frame when the airconditioning stopped at night was $22.2^{\circ} \mathrm{C}$ for scagliola, and $18.6^{\circ} \mathrm{C}$ for aluminum, and $19.1^{\circ} \mathrm{C}$ for steel.

Also in these results, it can be seen that the indoor temperature of the scagliola frame has a lower 


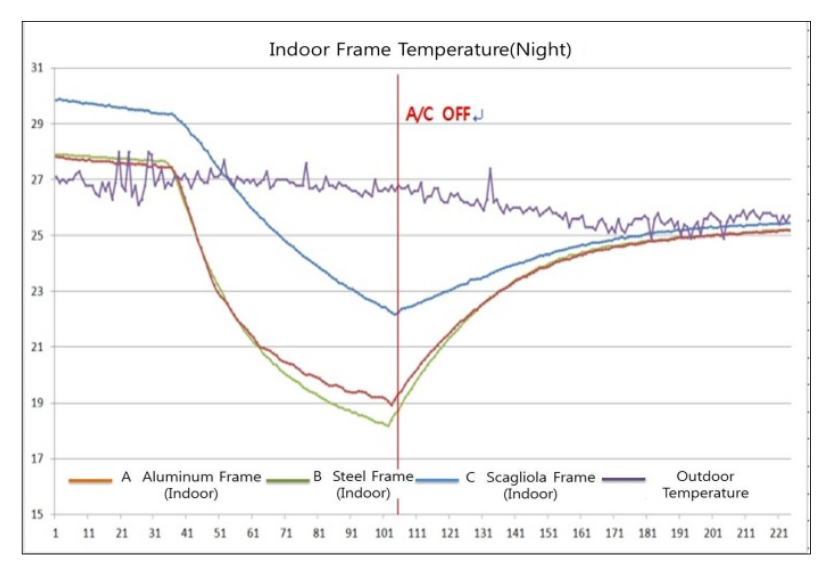

Fig.17. Indoor Frame Temperature (Night)

distribution than the other frames.

(D) Nighttime Outdoor Frame Temperature Distribution

The temperatures of the frames measured outdoors and at night, without daylight, are shown in Table 8. and Fig. 18.

Table 8. Outdoor Frame Temperature (Nighttime) $\left({ }^{\circ} \mathrm{C}\right)$

\begin{tabular}{c|ccccc}
\hline $\begin{array}{c}\text { Room } \\
\text { name }\end{array}$ & $\begin{array}{c}\text { Start } \\
\text { Temp. } \\
\left({ }^{\circ} \mathrm{C}\right)\end{array}$ & $\begin{array}{c}\text { Desired } \\
\text { temp. } \\
\left({ }^{\circ} \mathrm{C}\right)\end{array}$ & $\begin{array}{c}\mathrm{A} / \mathrm{C} \text { off } \\
{[\mathrm{C}]} \\
\left({ }^{\circ} \mathrm{C}\right)\end{array}$ & $\begin{array}{c}\text { Off } \\
\text { temp. }[\mathrm{D}] \\
\left({ }^{\circ} \mathrm{C}\right)\end{array}$ & $\begin{array}{c}|\Delta \mathrm{t}| \\
{[\mathrm{D}]-[\mathrm{C}]} \\
\left({ }^{\circ} \mathrm{C}\right)\end{array}$ \\
\hline Room A & 26.9 & 18.1 & 23.8 & 25.7 & 1.9 \\
Room B & 26.7 & 18.1 & 23.3 & 26.0 & 2.7 \\
Room C & 27.9 & 18.1 & 26.2 & 26.2 & 0.0 \\
\hline
\end{tabular}

Room A : Aluminum, Room B : Steel, Room C : Scagliola

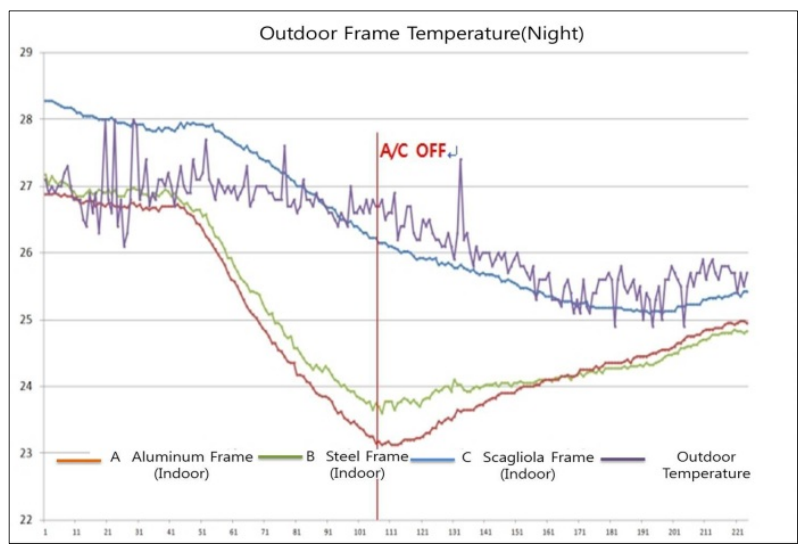

Fig.18. Outdoor Frame Temperature (Night)

The initial temperature for each frame at night was $26.9^{\circ} \mathrm{C}, 26.7^{\circ} \mathrm{C}$, and $27.9^{\circ} \mathrm{C}$ for aluminum, steel, and scagliola, respectively. At night, without daylight, when the indoor average temperature was $18.1^{\circ} \mathrm{C}$ after air-conditioning, the temperature distribution of each frame was $23.8^{\circ} \mathrm{C}$ for aluminum, $23.3^{\circ} \mathrm{C}$ for steel, and $26.2^{\circ} \mathrm{C}$ for scagliola.

Likewise, it can be seen that, among the three frames, the smallest temperature change was with the scagliola.

\section{Conclusion}

The purpose of this study was to evaluate the thermal performance by types of curtain wall frame. The thermal performance of curtain wall frames was analyzed through simulation and mock-up tests. The results of this study can be summarized as follows.

1) Through precedent study analysis, it was found that the most commonly used curtain walls are of metallic and aluminum frames, which cause the heat bridge phenomenon, and improvement studies are thus needed.

2) By using the heat transfer simulation with three frames of aluminum, steel, and scagliola, it showed that all three had little heat loss during both the summer and winter seasons.

3) The results from comparing frame temperature differences in the mock-up test experiment, show that scagliola had the lowest temperature difference for both night and day.

4) In comparing the frame thermal performance through the simulation and mock-up test, scagliola was found to be superior to aluminum and steel.

Therefore, it was found that the heat loss from frames can be reduced by applying the scagliola frame which improves the thermal performance over the aluminum and steel frames currently used in curtain wall structures.

\section{Acknowledgments}

This research was supported by the Chung-Ang University Excellent Student Scholarship.

\section{References}

1) Cho, B. H, Youn, K. J, Yim, H. C, Kim, J. H and Shin, S. H. (2010) Market Study of Steel Curtain Wall and Application for High-rise Buildings, KSSC, 22(2), pp.27-33.

2) Clarke, J. A., Janak, M., and Ruyssevelt, P. (1998) Assessing the overall performance of advanced glazing systems, Solar Energy, 63(4), pp.231-241.

3) Ganguli, U. and Quirouette R. L. (1987) Pressure equalization performance of a metal and glass curtain wall, Proceedings 1987 CSCE Centennial Conference Montreal, Quebec, 1, pp.127-144.

4) Ge H. (2002) Study on overall thermal performance of metal curtainwalls. Doctoral Dissertation, Concordia University, Montreal, Canada.

5) Ge, H and Fazio, P. (2004) Experimental investigation of cold draft induced by two different types of glazing panels in metal curtainwalls, Building and Environment, 39(2), pp.115-125.

6) Kim, B. S, Kim, T. Y. and Kim, K. H. (2005) Prediction Potential Condensation at the inside surface of the glazed curtain wall of high-rise residential buildings. Journal of Asian Architecture and Building Engineering., 3(2), pp.267-274.

7) Koo, Y. A. and Oh, C. W., (2011) A Study on the Thermal Performance of Curtain Wall Systems Using Fire-resistant, Lightweight Inorganic Composite Foam Board. Journal of KIAEBS, 5(4), pp.224-229.

8) Korea Meteorological Administration. (2011) Annual Climatological Report.

9) Lam, J. C., Tsang, C. L., Li, D. H. W. and Cheung, S. O. (2005), Residential building envelope heat gain and cooling energy requirements, Energy, 30(7), pp.933-951. 
10) Lee, J. S., Yim, H. C., Cho, B. H. and Kim, H. Y. (2011) An Experimental Study on Fire Resistance Performance of CurtainWall System with Steel-Aluminum Hybrid Frame, J. of Korean Institute of Fire Sci. \& Eng., 25(6).

11) Lee, K. H., Kang, K. N., and Mun, S. H., Operational Strategies of A.S.L(Artificial Solar Lavatory) for performance Evaluation of Curtain Wall, Proceedings 2009 SAREK Winter Conference KOFST, Seoul, 1, pp.110-116.

12) Miloslav, B and Martin, L. (2011) Interference of frame and glass systems and Their Impact On Thermal Performance Of Fenestration System. Procedia Engineering., 24, pp.375-379.

13) No, S. T. and Jeong, J. W. (2011) A Study on Analysis method of Curtain Wall Thermal Performance Comparing Simulation and Mock-up test, Journal of KIAEBS 5(1), pp.1-6.

14) No, S. T. and Kim, K. S. (2005) Analysis of the Thermal Performance of Curtain Walls in High-rise Residential Buildings. Journal of Asian Architecture and Building Engineering., 4(2), pp.525-532.

15) No, S. T., Kim, K. S and Jung, J. S. (2008) Simulation and mockup tests of the thermal performance of curtain walls, Energy and Building, 40(7), pp.1135-1144.

16) Richmana, R. and Pressnailb, K. D. (2010) Quantifying and predicting performance of the solar dynamic buffer zone (SDBZ) curtainwall through experimentation and numerical modeling, Energy and Buildings, 42(4), pp.522-533.

17) Sadineni, S. B., Madala, S., and Boehm, R.F. (2011) Passive building energy savings: A review of building envelope components, Renewable and Sustainable Energy Reviews, 15(8), pp.3617-3631.

18) Song, S. Y., Kim, S. M. and Park, H. S. (2006) Insulation Performance Evaluation of the Aluminum and PVC Framed Double Glazing Window Systems with Low-e Coating and Insulation Spacer, Architectural Insitute of Korea Journal. 22(12), pp.285-292.

19) Song, S. Y., Yi, J. S. and Koo, B. K., (2008) Insulation plan of aluminum curtain wall- fastening unit for high-rise residential complex, Building and Environment, 43(7), pp.1310-1317.

20) Sozer, H. (2010) Improving energy efficiency through the design of the building envelope, Building and Environment, 45(12), pp.2581-2593.

21) Yoon, J. H., Park, J. W., Kim, H. J., Lee, C. S., and Shin, W. C. (2009) Software Development on a Thermal Performance Evaluation and Economic Analysis of Window System for an Early Design Stage, Journal of the Korean Solar Energy Society. 29(1), pp.24-31. 